\title{
Evaluating Membrane Separation Effectiveness for Highly Concentrated Aqueous Media Applying Two-stage Reverse Osmosis Plant
}

\author{
T.A.Trifonova ${ }^{1}$, A.A. Povorov $^{2}$, L. A. Shirkin ${ }^{3}$, O.G. Selivanov ${ }^{4}$, M. E Ilina ${ }^{5}$ \\ ${ }^{1}$ Vladimir State University named after A. G. and N. G. Stoletovs, Vladimir, Russian Federation \\ tatrifon@mail.ru \\ ${ }^{2}$ BMT LLC, Vladimir, Russian Federation \\ vladimir@vladbmt.ru \\ ${ }^{3}$ Vladimir State University named after A. G. and N. G. Stoletovs, Vladimir, Russian Federation \\ shirkin76@mail.ru \\ ${ }^{4}$ Vladimir State University named after A. G. and N. G. Stoletovs, Vladimir, Russian Federation, \\ selivanov6003@mail.ru \\ ${ }^{5}$ Vladimir State University named after A. G. and N. G. Stoletovs, Vladimir, Russian Federation \\ ilina4@mail.ru
}

\begin{abstract}
The research considers the issues of evaluating membrane separation efficiency for highly concentrated aqueous media by reverse osmosis. The pilot two-stage reverse osmosis plant was used for the research. The specific membrane capacity and concentration rate were chosen as test parameters determining the membrane separation efficiency for highly concentrated aqueous media. Highly concentrated leachate from solid waste landfill of chemical oxygen demand up to $10700 \mathrm{mgO}_{2} / \mathrm{l}$ and $400 \mathrm{mg} \cdot$ eqv/l alkalinity were used as highly mineralized water medium for testing, applying two-stage reverse osmosis plant. It resulted in determining optimal technological parameters of highly mineralized leachate processing: operating pressure for the 1-st stage reverse osmosis separation - $60 \mathrm{kgf} / \mathrm{cm}^{2}$, concentration rate of the initial solution - by 2.9 times; operating pressure for the 2-nd stage reverse osmosis separation $-15 \mathrm{kgf} / \mathrm{cm}^{2}$, concentration rate of the $1 \mathrm{st}$ stage permeate - by 9 times. The research revealed the positive effect of preliminary acidification stage of highly concentrated aqueous media with high alkalinity for membrane separation process.
\end{abstract}

Key words: concentrate, concentration rate, highly concentrated waste water, membrane separation, membrane specific capacity, permeate, two-stage reverse osmosis plant,

\section{INTRODUCTION}

Nowadays the method of membrane desalination is widely used for processing mineralized water solutions, chemical and pharmaceutical liquid products, washing and working solutions, make-up water of machine-building, food, chemical, textile, fuel and energy and other branches of industry [1-5]. The traditional desalination method for such aqueous media includes pre-treatment and one- or twostages reverse osmosis desalination plants. Membrane desalination is also increasingly used in the treatment of solid waste landfills leachate. The treatment of highly concentrated waste leachate is a more complex multi-stage technological process [6-9]. It depends on the complex and unique composition of contaminated leachate, and the treatment process of such wastewater is studied in the differentiated manner and simultaneously with the search for the most appropriate integrated technologies, applying experimental installations if possible. But anyway, the stage of membrane desalination remains one of the key stages in the treatment of highly mineralized leachate. The final target of contaminated leachate desalination is to receive maximum amount of processed water meeting the discharge requirements into the fishery water bodies (permeate) and the minimum amount of concentrate to be returned to the landfill site. To reach this objective, it is necessary to develop membrane separation technological diagram, providing multi-stage treatment of landfill leachate, and reduction of both permeate and concentrate amount.

The research objective is to evaluate the membrane separation effectiveness for highly mineralized leachate applying pilot two-stage reverse osmosis plant.

\section{RESEARCH OBJECTS AND METHODS}

The experiments focused on deep desalination of preprepared leachate from the landfill "Dmitrovskiy" were conducted using two-stage reverse osmosis membrane pilot plant developed by "BMT ltd." in Vladimir, shown in Figure 1. 


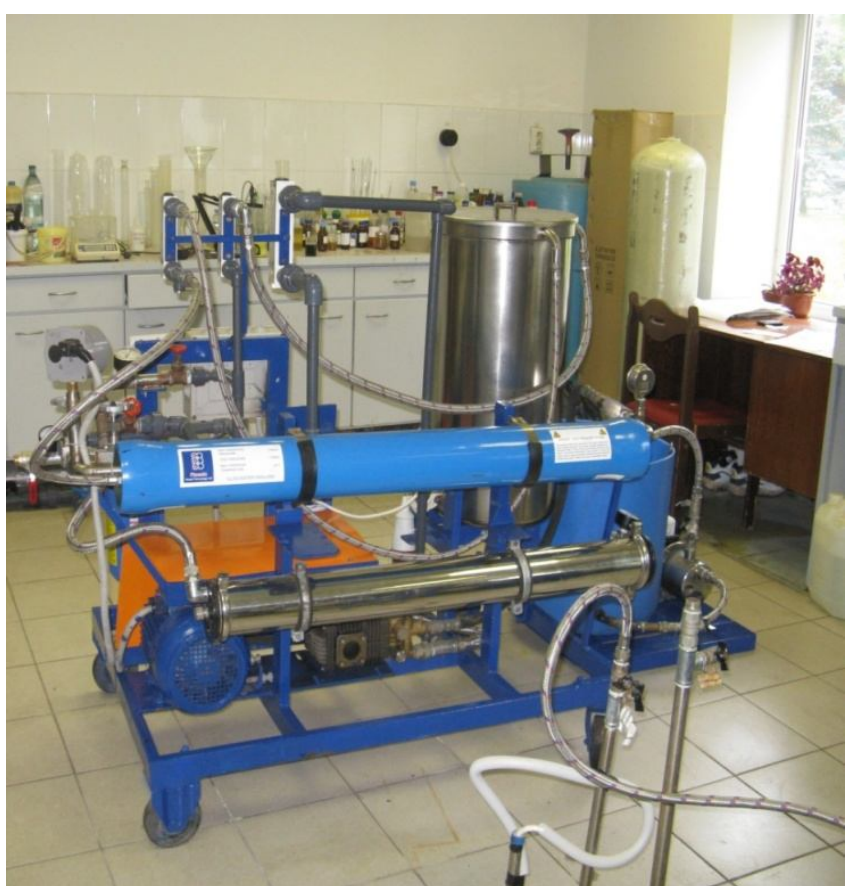

Figure 1: Two-stage reverse osmosis membrane pilot plant.

The principle technological diagram of pilot twostage reverse osmosis plant is shown in Figure 2.

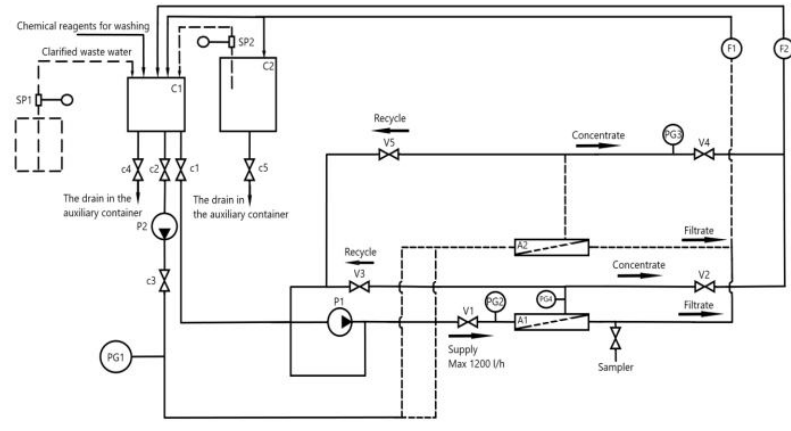

Figure 2: Principle technological diagram of pilot two-stage reverse osmosis plant

SP1, SP2 - submersible pumps; C1, C2 - container; c1, c2, c3, c4, c5 - crane; V1,V2,V3,V4,V5 - valve; PG1, PG2,PG3, PG4 pressure gauge; F1, F2 - flowmeter; A1, A2 - membrane apparatus; $\mathrm{S}$ - sampler; P1, P2 - high pressure plunger pump

The clarified initial leachate after pre-treatment using granular filter was poured into the tank $\mathrm{C} 1$ and further was fed to the first stage of reverse osmosis membrane plant A1 by the high-pressure plunger pump P1. At the first stage of the plant under the operating pressure of up to $60 \mathrm{~atm}$., the waste water was split into two streams: purified and partially desalinated water (first stage permeate), collected in the tank $\mathrm{C} 2$, and the first stage concentrate which was constantly looped to the tank $\mathrm{C} 1$. When reaching the specified degree of permeate collection, the process of waste water concentration was stopped. After the first stage of membrane separation concentrate from tank $\mathrm{C} 1$ was discharged into the intermediate auxiliary tank. The tank $\mathrm{C} 1$ was washed with tap water and permeate from the first stage of membrane separation was pumped into the tank $\mathrm{C} 2$. The first stage permeate was fed to the second stage A2 membrane apparatus by a plunger pump P2. The waste water was finally desalinated at the second stage under the operating pressure of max $15 \mathrm{~atm}$.

The operating pressure at the inlet and outlet of the membrane vessels $\mathrm{A} 1$ and $\mathrm{A} 2$ was monitored according to the pressure gauges PG2 - PG4 and PG1 - PG3 readings respectively.

The permeate flow rate at stages 1 and 2 is determined by flow meter F1, and the concentrate flow rate - according to the flow meter F2.

Physical and chemical parameters detection in the feed waste water, as well as purified water after the first and second membrane filtration stages was carried out in compliance with GOST and Federal Environmental Regulations.

Since landfill leachate contains sufficiently large amount of mechanical and colloidal particles, as well as highly molecular organic substances, leachate samples were preliminary treated using laboratory mechanical granular filter with two-layer loading, consisting of anthracite and quartz sand, before studying the process of membrane filtration,

The membrane element RE 4040SN produced by CSM (South Korea) was chosen for the first stage of reverse osmosis separation for contaminated leachate and membrane element RE 4040BL was used for the second stage of reverse osmosis separation.

The initial solution composition of contaminated leachate is shown in table 1 .

Table 1: Initial solution composition of contaminated leachate

\begin{tabular}{|l|l|l|l|}
\hline Item & $\begin{array}{l}\text { Measure } \\
\text { unit } \\
\mathrm{pH}\end{array}$ & $\begin{array}{l}\text { Fed } \\
\text { landfill } \\
\text { leachate }\end{array}$ & Regulation \\
\hline Hardness & $\mathrm{mg} \cdot \mathrm{eqv} / \mathrm{l}$ & 32 & $\begin{array}{l}\text { PND F } \\
14.1: 2: 34.121-97\end{array}$ \\
\hline Calcium & $\mathrm{mg} / \mathrm{l}$ & 400 & $\begin{array}{l}\text { GOST 31954- } \\
2012\end{array}$ \\
\hline Magnesium & $\mathrm{mg} / \mathrm{l}$ & 144 & $\begin{array}{l}\text { GOST 31869- } \\
2012\end{array}$ \\
\hline Alkalinity & $\mathrm{mg} \cdot \mathrm{eqv} / \mathrm{l}$ & 400 & $\begin{array}{l}\text { GOST }-31957- \\
2012\end{array}$ \\
\hline Boron & $\mathrm{mg} / \mathrm{l}$ & 17.2 & $\begin{array}{l}\text { GOST 31949- } \\
2012\end{array}$ \\
\hline Iron $\left(\mathrm{Fe}_{\text {total }}\right)$ & $\mathrm{mg} / \mathrm{l}$ & 12.49 & $\begin{array}{l}\text { PND F } \\
14.1: 2: 4.50-96\end{array}$ \\
\hline Cadmium & $\mathrm{mg} / \mathrm{l}$ & 0.0003 & $\begin{array}{l}\text { GOST 31870- } \\
2012\end{array}$ \\
\hline & & &
\end{tabular}


T.A.Trifonova et al., International Journal of Emerging Trends in Engineering Research, 8(3), March 2020, 906 - 910

\begin{tabular}{|c|c|c|c|}
\hline Silicon & $\mathrm{mg} / \mathrm{l}$ & 37.83 & $\begin{array}{l}\text { PND F } \\
14.1: 2: 4.215-06\end{array}$ \\
\hline Manganese & $\mathrm{mg} / \mathrm{l}$ & 1.36 & GOST 4974-2014 \\
\hline Zinc & $\mathrm{mg} / \mathrm{l}$ & 0.18 & $\begin{array}{l}\text { GOST 31870- } \\
2012\end{array}$ \\
\hline $\begin{array}{l}\text { Ammonia } \\
\left(\mathrm{NH}_{4}^{+}\right)\end{array}$ & $\mathrm{mg} / \mathrm{l}$ & 6300 & $\begin{array}{l}\text { GOST 33045- } \\
2014\end{array}$ \\
\hline $\begin{array}{l}\text { Nitrates } \\
\left(\mathrm{NO}_{3}^{--}\right)\end{array}$ & $\mathrm{mg} / \mathrm{l}$ & 482 & GOST 18826-73 \\
\hline $\begin{array}{l}\text { Sulphates } \\
\left(\mathrm{SO}_{4}^{--}\right)\end{array}$ & $\mathrm{mg} / \mathrm{l}$ & 50 & $\begin{array}{l}\text { GOST -31940- } \\
2012\end{array}$ \\
\hline $\begin{array}{l}\text { Chlorides } \\
\left(\mathrm{Cl}^{-}\right)\end{array}$ & $\mathrm{mg} / \mathrm{l}$ & 7112 & GOST 4245-72 \\
\hline $\begin{array}{l}\text { Anionic } \\
\text { surfactants }\end{array}$ & $\mathrm{mg} / \mathrm{l}$ & 65 & $\begin{array}{l}\text { PND F } \\
14.1: 2: 4.15-95\end{array}$ \\
\hline $\begin{array}{l}\text { Nonionic } \\
\text { surfactants }\end{array}$ & $\mathrm{mg} / \mathrm{l}$ & 46.25 & $\begin{array}{l}\text { PND F } \\
14.1: 2: 4.194-2003\end{array}$ \\
\hline Petroleums & $\mathrm{mg} / \mathrm{l}$ & & $\begin{array}{l}\text { GOST 31953- } \\
2012\end{array}$ \\
\hline COD & $\mathrm{mgO}_{2} / \mathrm{l}$ & 10733 & $\begin{array}{l}\text { GOST P 52708- } \\
2007\end{array}$ \\
\hline Color & degree & 18000 & $\begin{array}{l}\text { GOST -31868- } \\
2012\end{array}$ \\
\hline Salinity & $\mathrm{mg} / \mathrm{l}$ & 31500 & $\begin{array}{l}\text { GOST P 54316- } \\
2011\end{array}$ \\
\hline
\end{tabular}

Table 2: The dependence of the membrane specific performance on the concentration degree without initial solution $\mathrm{pH}$ adjusting.

\begin{tabular}{|l|l|l|l|l|}
\hline $\begin{array}{l}\text { Concentrat } \\
\text { ing time, } \\
\text { min }\end{array}$ & $\mathrm{t},{ }^{\circ} \mathrm{C}$ & $\begin{array}{l}\text { Element } \\
\text { capacity, } \\
1 / \mathrm{h}\end{array}$ & $\begin{array}{l}\text { Membrane } \\
\text { specific } \\
\text { capacity, } \\
1 / \mathrm{m}^{2} \mathrm{~h}\end{array}$ & $\begin{array}{l}\text { Permea } \\
\text { te } \\
\text { selectio } \\
\text { n rate, } \\
\%\end{array}$ \\
\hline 0 & 14 & 225 & 32.1 & - \\
\hline 5 & 14.5 & 159 & 22.7 & 5.7 \\
\hline 15 & 15 & 133 & 18.9 & 14.3 \\
\hline 35 & 20 & 106 & 15.1 & 28.5 \\
\hline 50 & 25 & 62 & 8.9 & 42.9 \\
\hline 60 & 26 & 58 & 8.3 & 45.7 \\
\hline 65 & 30 & 46 & 6.5 & 57.1 \\
\hline 80 & 31 & 34 & 4.8 & 65.7 \\
\hline
\end{tabular}

Table 3: The dependence of membrane specific performance on concentration degree during acidification of the initial solution.

\section{RESEARCH RESULTS AND DISCUSSION}

The chemical composition analysis of the initial contaminated leachate revealed its high alkalinity index. To reduce it, it was decided to make $\mathrm{pH}$ correction of the fed leachate solution in order to decrease calcium carbonate concentration, which easily precipitates on the membranes surface during concentrating. To assess the pre-acidification impact of the initial solution on first stage membrane separation, the experiments were conducted with preclarified leachate at of the initial sample solution $\mathrm{pH}$ and clarified filtration water acidified with sulfuric acid up to $\mathrm{pH}$ $=7$. The process of first stage reverse osmosis separation was carried out at the pilot plant under the operating pressure of up to $60 \mathrm{~atm}$., the initial solution feeding to the membrane element $-1.3 \mathrm{~m}^{3} /$ hour, the separated solution temperature $-25^{\circ} \mathrm{C}$, the initial capacity of the membrane element for leachate - $2251 /$ hour. During the experiments, the dependence of membrane specific performance on the concentration degree (permeate selection) was determined without any $\mathrm{pH}$ adjusting of the feeding solution medium and with the initial solution acidification up to $\mathrm{pH}=7$.

Test results are presented in tables 2 and 3.

\begin{tabular}{|l|l|l|l|l|}
\hline $\begin{array}{l}\text { Concentr } \\
\text { ating } \\
\text { time, } \\
\text { min }\end{array}$ & $\mathrm{t},{ }^{\circ} \mathrm{C}$ & $\begin{array}{l}\text { Element } \\
\text { capacity, } \\
\mathrm{l} / \mathrm{h}\end{array}$ & $\begin{array}{l}\text { Membrane } \\
\text { specific } \\
\text { capacity, } \\
\mathrm{l} / \mathrm{m}^{2} \mathrm{~h}\end{array}$ & $\begin{array}{l}\text { Permeate } \\
\text { selection } \\
\text { rate, \% }\end{array}$ \\
\hline 0 & 20 & 287 & 41 & - \\
\hline 10 & 22 & 228 & 32.6 & 17.1 \\
\hline 15 & 23 & 193 & 27.6 & 28.6 \\
\hline 20 & 24 & 141 & 20.1 & 40.0 \\
\hline 30 & 25 & 101 & 14.5 & 51,4 \\
\hline 40 & 26 & 65 & 9.2 & 57.1 \\
\hline 45 & 27 & 48 & 6,9 & 62.8 \\
\hline 60 & 30 & 41 & 5.8 & 65.7 \\
\hline
\end{tabular}

The comparative analysis of tables 2 and 3 shows that preacidification of the initial clarified leachate before reverse osmosis separation allows to increase membrane specific performance significantly, that means that the process of the first stage reverse osmosis separation is more efficient.

The chemical analysis of the first stage permeate (table 4) showed that the first stage reverse osmosis membrane treatment of the contaminated leachate allows to reaching sufficiently high degree of contaminants removal from the leachate, but permeate quality regarding a number of indicators (ammonia, nitrates, chlorides, total salinity) does not meet the standard parameters. In order to reach the required degree of purification, experiments on the first stage permeate of reverse osmosis separation were carried out, i.e. the second stage treatment of leachate was performed. 
The second stage reverse osmosis separation was carried out under the operating pressure up to 15 bar, initial solution feeding to the membrane element of $1.3 \mathrm{~m}^{3} /$ hour, the filtered solution temperature of $25^{\circ} \mathrm{C}$, initial performance of the membrane element of 319 1/h.

In the course of experiments on reverse osmosis separation at the second stage of treatment, the dependence of the membrane specific performance fluctuations on concentration degree of (permeate selection) was also determined. It is shown in Figure 3.

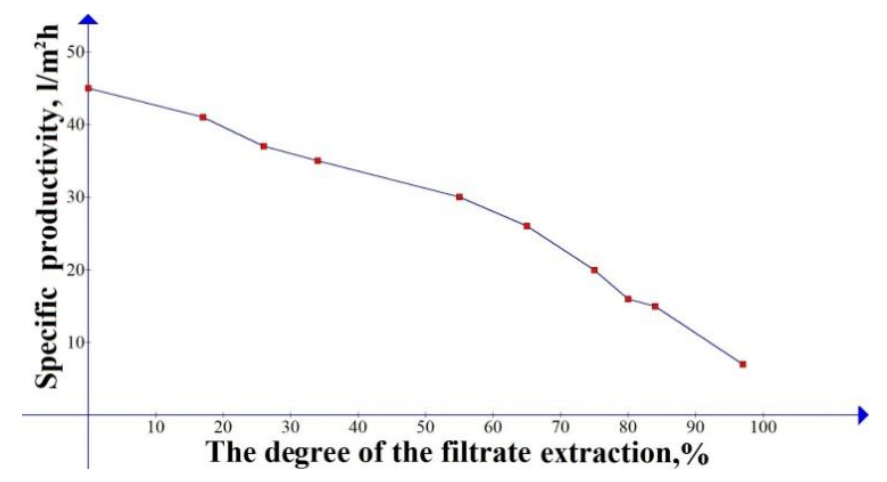

Figure 3: Dependence of the specific productivity of the membrane on the degree of filtrate selection

The chemical analysis results of leachate reverse osmosis desalination after the first and second stages are presented in table 4.

Table 4: Chemical analysis results of leachate reverse osmosis desalination after the first and second stages

\begin{tabular}{|c|c|c|}
\hline \multirow[t]{2}{*}{ Item, unit } & \multicolumn{2}{|c|}{$\begin{array}{l}\text { Reverse osmosis } \\
\text { separation }\end{array}$} \\
\hline & $\begin{array}{l}\text { 1-st stage } \\
\text { permeate }\end{array}$ & $\begin{array}{l}\text { 2-nd stage } \\
\text { permeate }\end{array}$ \\
\hline $\mathrm{pH}$ & 6.69 & 6.1 \\
\hline Hardness, mgeqv/l & 0.18 & 0.04 \\
\hline Calcium, mg/l & 2.6 & 0.6 \\
\hline Magnesium, mg/l & 0.6 & 0.12 \\
\hline Alkalinity, mgeqv/l & 20 & 3.2 \\
\hline Boron, mg/l & 6.1 & 4.7 \\
\hline Iron $\left(\mathrm{Fe}_{\text {total }}\right), \mathrm{mg} / \mathrm{l}$ & 0.01 & 0.01 \\
\hline Cadmium, mg/l & $\mathrm{n} / \mathrm{d}$ & $\mathrm{n} / \mathrm{d}$ \\
\hline Silicon, $\mathrm{mg} / \mathrm{l}$ & 0.15 & 0.04 \\
\hline Manganese, $\mathrm{mg} / \mathrm{l}$ & 0.0016 & 0,004 \\
\hline Zinc, $\mathrm{mg} / \mathrm{l}$ & 0.001 & $\mathrm{n} / \mathrm{d}$ \\
\hline Ammonia $\left(\mathrm{NH}_{4}^{+}\right), \mathrm{mg} / \mathrm{l}$ & 276 & 54 \\
\hline Nitrates $\left(\mathrm{NO}_{3}{ }^{--}\right), \mathrm{mg} / \mathrm{l}$ & 110 & 33 \\
\hline Sulphates, mg/l & 18 & 9 \\
\hline Chlorides $\left(\mathrm{Cl}^{-}\right), \mathrm{mg} / \mathrm{l}$ & 420 & 46 \\
\hline Anionic surfactants, mg/l & 1.25 & 0.4 \\
\hline
\end{tabular}

\begin{tabular}{|l|l|l|}
\hline \multirow{2}{*}{ Item, unit } & \multicolumn{2}{|l|}{$\begin{array}{l}\text { Reverse osmosis } \\
\text { separation }\end{array}$} \\
\cline { 2 - 3 } & $\begin{array}{l}\text { 1-st stage } \\
\text { permeate }\end{array}$ & $\begin{array}{l}\text { 2-nd stage } \\
\text { permeate }\end{array}$ \\
\hline Nonionic surfactants, $\mathrm{mg} / \mathrm{l}$ & $<0.02$ & $<0.02$ \\
\hline Petroleums, mg/l & 0.25 & 0.12 \\
\hline COD, $\mathrm{mgO}_{2} / \mathrm{l}$ & 91 & 29 \\
\hline Color, degree & 17 & 12 \\
\hline Salinity, $\mathrm{mg} / \mathrm{l}$ & 1675 & 232 \\
\hline
\end{tabular}

Analyzing the research data, it can be concluded that twostage membrane reverse osmosis treatment of contaminated leachate provides the required degree purification rate thus meeting the discharge requirements for fishery water bodies regarding all indicators, except for ammonium nitrogen. To reach the standard indicator, the third stage of reverse osmosis separation is no longer reasonable, so the additional technological stage is required to process the second stage permeate by using other physical and chemical methods, such as adsorption or ion exchange.

\section{CONCLUSION}

Based on the research results we have worked out the optimum treatment parameters for pre-clarified concentrated leachate using pilot two-stage reverse osmosis plant: operating pressure at the 1-stage reverse osmosis was 60 $\mathrm{kgf} / \mathrm{cm}^{2}$, concentration degree $\mathrm{K}=2.9$; operating pressure at the 2-stage reverse osmosis was $15 \mathrm{kgf} / \mathrm{cm}^{2}$, concentration degree $\mathrm{K}=9$.

The membrane specific performance showed the significant increase if initial solution is acidified and decreases alongside concentration increase.

The developed two-stage reverse osmosis pilot plant provides solving the problems of processing highly concentrated waste water not only from landfills, but also mineralized aqueous media of such industries as engineering, chemical, food, power engineering, petroleumrefining and others.

\section{ACKNOWLEDGMENT}

This work was financially supported by project No. 05.607.21.0314 by the Ministry of Science and Higher Education of the Russian Federation (Agreement dated 06.12.2019 No. 075-15-2019-1837) within the framework of the Federal Target Program "Research and Development in Priority Directions for the Development of the Russian Science and Technology Complex for 2014-2020"

The research results were obtained using the scientific equipment of the collective use center "Inter-regional multidisciplinary and interdisciplinary center for collective use of perspective and competitive technologies in the directions of development of industrial industry". 


\section{REFERENCES}

1. W. J. Lee, P. S. Goh, W. J. Lau, C. S. Ong, A. F. Ismail "Antifouling zwitterion embedded forward osmosis thin film composite membrane for highly concentrated oily wastewater treatment." Separation and Purification Technology. 2019, Vol. 2141, pp. 4050. https://doi.org/10.1016/j.seppur.2018.07.009

2. Chukhlanov V., Selivanov O., Pikalov E., Chesnokova C., Podolets A. "Purification of Water from Fluoride Ions by a Lanthanum-Containing Ceramic Material." Ecology and Industry of Russia. 2018; 22(8):28-31. (In Russ.)

3. J. Bohdziewicz, E. Sroka "Integrated system of activated sludge-reverse osmosis in the treatment of the wastewater from the meat industry." Process Biochemistry. 2005, Vol. 40, № 5, pp. 1517-1523. https://doi.org/10.1016/j.procbio.2003.11.047

4. P. Menchik, C. I. Moraru "Nonthermal concentration of liquid foods by a combination of reverse osmosis and forward osmosis. Acid whey: A case study." Journal of Food Engineering. 2019, Vol. 253, pp. 40-48.

5. G. Han, C.-Z. Liang, T.-S. Chung, M. Weber, C. Maletzko "Combination of forward osmosis (FO) process with coagulation/flocculation (CF) for potential treatment of textile wastewater." Water Research. 2016,Vol. 9115, pp. 361-370. https://doi.org/10.1016/j.watres.2016.01.031

6. T.A. Trifonova, L.A. Shirkin, O.G. Selivanov, M.E. Ilina“"Assessment of Aqueous Solutions Concentration Efficiency of Mineral Salts and Organic Media Applying Rotary-Film Evaporator for Natural and Waste Water Treatment." International Journal of Emerging Trends in Engineering Research. 2019, Vol.7, № 12, pp. 857-860.

https://doi.org/10.30534/ijeter/2019/227122019

7. T.A. Trifonova, S.I. Roschina, L.A. Shirkin, O.G. Selivanov, M.E. Ilina "An integrated innovative technology for the treatment of municipal solid waste landfill leachate." Biosciences Biotechnology Research Asia. 2015, Vol.12, № 3, pp. 2481-2488. https://doi.org/10.13005/bbra/1927

8. Trifonova T., Povorov A., Shirkin L., Selivanov O., Il'ina M. "Package technology of treatment of seepage waters at municipal solid waste landfills." Ecology and industry of Russia. 2015; 19(11):4-9. (in Russ.)

9. A. Awad, F. Al Bajari, F. Al Adday "A Case Study on Rainwater Harvesting and Reuse in Jordan" International Journal of Emerging Trends in Engineering Research. 2019, Vol.7, № 11, pp. 398-402. https://doi.org/10.30534/ijeter/2019/017112019 